\title{
The Description of Elderly Social Interaction during COVID-19 Pandemic in Nursing Home of Jember
}

\section{Bela Aprilia Nuraini ${ }^{1 *}$, Latifa Aini Susumaningrum ${ }^{2}$, Tantut Susanto ${ }^{3}$, Hanny Rasni ${ }^{4}$, Fahruddin Kurdi ${ }^{5}$, Siswanto 6}

\begin{abstract}
${ }^{1}$ Faculty of Nursing, University Jember, Indonesia; belanuraini95@gmail.com (Corresponding Author) 2,3,4,5 Department of Caring for Risk and Vulnerable Population in Community, Faculty of Nursing, University of Jember, Indonesia ${ }^{6}$ Nursing Home of Jember, Jember, Indonesia
\end{abstract}

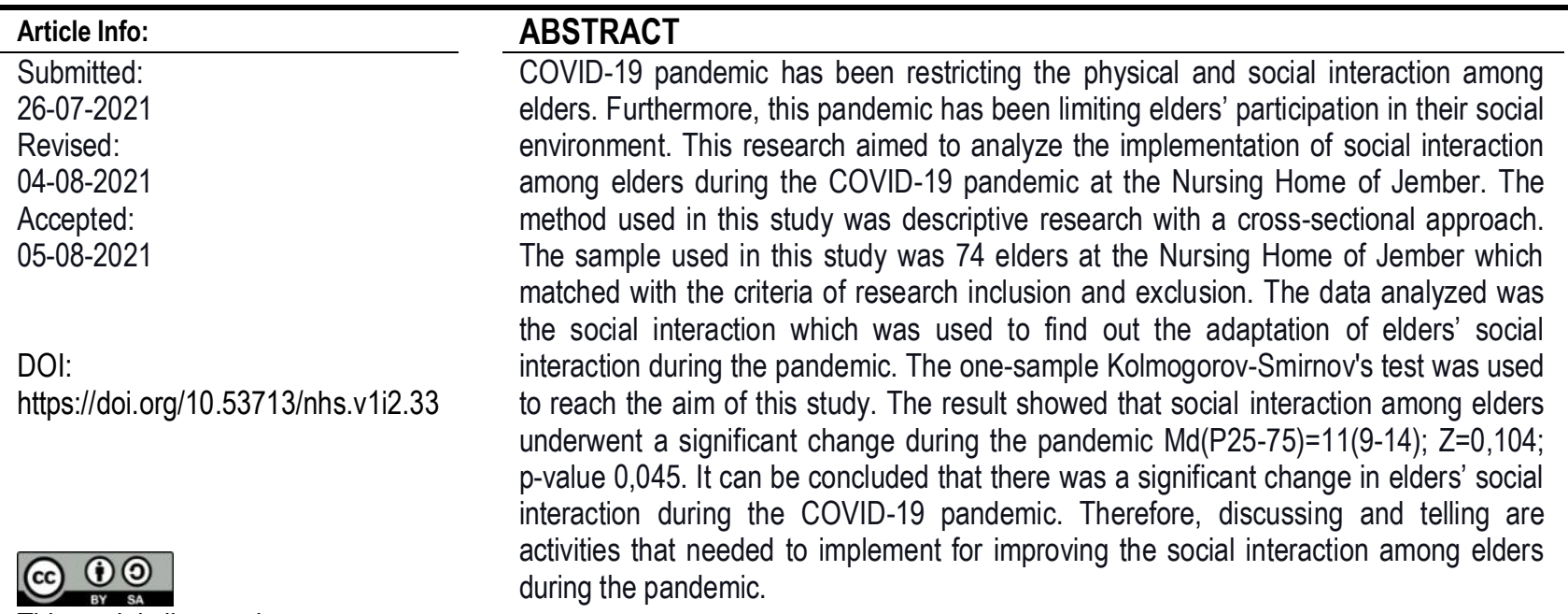

This work is licensed under CC BY-SA License.

Keywords: COVID-19; elders; nursing home; physical interaction; social interaction

\section{INTRODUCTION}

COVID-19 or Severe Acute Respiratory Syndrome Coronavirus 2 (SARS-CoV-2) is a virus that attacks the respiratory system. The virus has spread in all parts of the world, including Indonesia (Harahap, 2020). During the COVID-19 pandemic, concern for the elderly has increased which is described as a problem for the elderly as a homogeneous group that is very vulnerable to COVID-19 transmission (Bergman et al., 2020). The elderly are one of the risk groups experiencing morbidity and mortality due to the COVID-19 pandemic (Kemenkes RI, 2020). Based on data from the Centers for Disease Control and Prevention (CDC) reported on 12 October 2020, the number of cases COVID19 in elderly ages $65-74$ as many as $422.003(7.6 \%)$, aged 75-84 years as many as 239.388 ( $4.3 \%)$, and ages 85 years and over as many as 175,516 (3.1\%) (CDC, 2020). The total number of COVID-19 cases in the elderly aged over 65 years in Indonesia reported on 23 April 2020 was 731 cases (Deputi Bidang Perlindungan Hak Perempuan, 2020).

COVID-19 is an infectious disease that spreads rapidly (Quyumi \& Alimansur, 2020). The elderly are a group that is more susceptible to being infected with COVID-19. This vulnerability is caused by a decrease in the immune system and comorbid diseases in the elderly (Wasityastuti et al., 2020). The elderly who are in nursing homes have a risk of mortality high as COVID-19 (Wammes et al., 2020). Based on these problems, the nursing home manager implemented policies such as limiting family and friend visits, limiting social interaction, limiting joint activities, and using PPE by staff (Anderson et al., 2020). The policy was carried out to control transmission and avoid high mortality in the elderly (Wammes et al., 2020). Policies social distancing also be applied to reduce the spread of COVID-19 (Sizoo et al., 2020). The social distancing policy can hinder physical interaction and social interaction (Li et al., 2020).

A nursing home is a place intended for the elderly to stay alive without relying on help from children or family (Afriansyah \& Santoso, 2019). The elderly who are in the nursing home carry out the programs provided by the nursing home to fill their spare time, such as social guidance activities, spiritual guidance, recreation, talent distribution, group therapy, and gymnastics (Sipayung et al., 2015). Based on the results of an interview with one of the elderly caregivers at the nursing home of Jember, it was stated that before the COVID-19 pandemic the elderly visited each other's rooms 
to share and interact with each other, besides that eating activities were carried out together with other elderly people in the same guesthouse, but during the COVID-19 pandemic, in carrying out their activities, the elderly are recommended to apply health protocols such as social distancing, the use of masks, restrictions on the activities of the elderly visiting other elderly rooms, and decreasing the number of family visits.

Reduced outdoor activity and reduced social interaction can harm physical and mental health in the elderly (Lim et al., 2020). Lack of social interaction in the elderly can cause feelings of isolation so that the elderly choose to stay away from their environment and feel isolated and ultimately depressed, this can affect the quality of life of the elderly (Andesty \& Syahrul, 2018). Based on this data, it is necessary to conduct a study on the social interaction of the elderly in the COVID-19 pandemic situation, the researcher aims to research the Description of Social Interaction in the Elderly during the COVID-19 Pandemic at the Nursing Home of Jember. The results of this study are expected to be a source of information regarding the description of the social interaction of the elderly during the COVID-19 pandemic and be used as input to optimize the ability of social interaction in the elderly.

\section{METHOD}

The research design used in this research is descriptive with a cross-sectional approach. The population in this study were the elderly at the nursing home of Jember as many as 140 elderly. With a sample of 74 elderly. The sampling technique in this research is total sampling. Researchers take data in a nursing home in April 2021. Stages data collection is to explain the intent and purpose of the study and proposed consent form (informed consent) signed by the elderly when the elderly are willing to become respondents, conduct screening symptom COVID-19, fill sheet characteristics of the elderly, test the Mini-Mental State Examination (MMSE) and filling out the Index of Social Interaction (ISI) questionnaire. The research team and the elderly wash their hands using soap and running water/hand sanitizer and keep their distance when interacting. The research team used PPE such as surgical masks, face shields, and aprons.

Data analysis carried out in this study is univariate analysis. Social interaction data was tested using the onesample Kolmogorov-Smirnov test to determine the significance of changes in the social interaction of the elderly and the results of each indicator consisting of indicators of independence, social curiosity, interaction, participation in the society, and feeling of safety. Significant changes in social interaction with $p$-value $<0.05$. Numerical data such as age and length of stay in the institution show that the data are not normally distributed, so they are presented in terms of medians and 25-75 percentiles. Categorical data such as gender, marital status are presented in numbers and percentages. This research was conducted an ethical test at the Faculty of Nursing, University of Jember and was declared to have passed ethics through the KEPK of the Faculty of Nursing, the University of Jember with No. 53/UN25.1.14/KEPK/2021.

\section{RESULT}

\section{Characteristics of the Elderly}

The description of the characteristics of the elderly at the nursing home of Jember is shown in table 1.

Table 1. Characteristics of the elderly during the COVID-19 pandemic based on age, length of stay in nursing homes, gender, marital status at the nursing home of Jember, April 2021 ( $n=74)$

\begin{tabular}{lc}
\hline \multicolumn{1}{c}{ Characteristics of the elderly } & $\mathbf{n}(\%)$ \\
\hline $\begin{array}{l}\text { Age (years) } \\
\text { Md }\left(P_{25}-P_{75}\right)\end{array}$ & $69(63.5-76)$ \\
\hline $\begin{array}{l}\text { Long stay in the nursing home (years) } \\
\text { Md }\left(P_{25}-P_{75}\right)\end{array}$ & $2(1-8)$ \\
\hline $\begin{array}{l}\text { Gender } \\
\text { Male }\end{array}$ & $33(44.6)$ \\
Female & $41(55.4)$ \\
\hline Marital status & \\
$\quad$ Not married & $4(5.4)$ \\
Married & $16(21.6)$ \\
Widow/widower & $54(73.0)$ \\
\hline
\end{tabular}


The elderly according to age have a median value of 69 years. The length of stay in the nursing home has a median value of 2 years. Most respondents have sex as many women as 41 elderly (55.4\%). The marital status of the elderly is mostly widows/widowers, namely 54 elderly (73.0\%).

\section{Elderly Social Interaction during COVID-19 Pandemic}

An overview of the index of social interaction indicators in the elderly during the COVID-19 pandemic at the nursing home of Jember is shown in Table 2.

Table 2. Distribution of the index of social interaction indicator in the elderly during the COVID-19 pandemic at the nursing home of Jember in April 2021 ( $n=74)$

\begin{tabular}{lccc}
\hline \multicolumn{1}{c}{ Variable } & Md (P25-75) & $\mathbf{Z}$ & p-value \\
\hline Independence Indicator & $4(3-4)$ & 0.369 & 0.000 \\
Do you have motivation to live an active lifestyle? & $1(1-1)$ & 0.512 & 0.000 \\
Do you take an active approach towards your life? & $1(1-1)$ & 0.489 & 0.000 \\
Are you motivated to live a healthy life? & $1(1-1)$ & 0.531 & 0.000 \\
Do you have a regular or routine lifestyle? & $1(1-1)$ & 0.489 & 0.000 \\
\hline Social Curiosity Indicator & $2(1-3)$ & 0.182 & 0.000 \\
Do you read newspapers regularly? & $0(0-0)$ & 0.518 & 0.000 \\
Do you read books or magazines regularly? & $0(0-0)$ & 0.507 & 0.000 \\
Do you try to use new equipments like a video? & $0(0-1)$ & 0.409 & 0.000 \\
Do you have any hobby? & $1(0-1)$ & 0.409 & 0.000 \\
Do you have feeling of importance in the society? & $1(1-1)$ & 0.477 & 0.000 \\
\hline Interaction Indicator & $2(1-3)$ & 0.324 & 0.000 \\
Do you often communicate with your family members? & $0(0-1)$ & 0.444 & 0.000 \\
Do you communicate with non-family persons regularly? & $1(0-1)$ & 0.464 & 0.000 \\
Do you interact with non-family persons regularly? & $1(0-1)$ & 0.464 & 0.000 \\
\hline Participation in the Society Indicator & $3(1-4)$ & 0.213 & 0.000 \\
Do you have chance to participate in social groups? & $1(0-1)$ & 0.389 & 0.000 \\
Do you have chance to participate in your neighborhood affairs? & $1(0-1)$ & 0.457 & 0.000 \\
Do you watch television? & $1(0-1)$ & 0.357 & 0.000 \\
Do you have an active role in the society or social affairs? & $0(0-1)$ & 0.347 & 0.000 \\
\hline Feeling of Safety Indicator & $2(1-2)$ & 0.408 & 0.000 \\
Do you have someone to counsel with in difficult situation? & $1(0-1)$ & 0.430 & 0.000 \\
Do you have someone to support you in emergency? & $1(1-1)$ & 0.489 & 0.000 \\
\hline Social Interaction & $11(9-14)$ & 0.104 & 0.045 \\
\hline
\end{tabular}

According to the results of statistical calculations in Table 2 using one-sample Kolmogorov-Smirnov, it was found that the elderly independence indicator experienced significant changes during the COVID-19 pandemic $(Z=0.369 ; p$ value 0.000$)$. Indicators of social curiosity elderly undergo significant changes during a pandemic COVID-19 ( $Z=0.182$; $p$ value 0.000$)$. The interaction indicators of the elderly experienced significant changes during the COVID-19 pandemic $(Z=0.324 ; p$-value 0.000$)$. The indicators of participation in the society of the elderly experienced significant changes during the COVID-19 pandemic ( $Z=0.213 ; p$-value 0.000$)$. The indicator of feeling safe in the elderly experienced significant changes during the COVID-19 period $(Z=0.408$; $p$-value 0.000$)$. The social interaction of the elderly at the nursing home of Jember experienced significant changes during the COVID-19 pandemic ( $Z=0.104 ; p$-value 0.045$)$.

\section{DISCUSSION}

\section{Characteristics of the Elderly}

The results showed that the mean age of the elderly was 69 years. This is because the elderly who live in the nursing home of Jember are mostly over 60 years old, which can be called elderly. The results of this study are supported by research that has been carried out (Bergman et al., 2020) which explains that the elderly as respondents have an age range of 60-92 years and the average elderly is 69 years old. Based on the length of stay in the nursing home, it shows that the length of stay in the institution has a median value of 2 years. This is because the elderly have 
lived in the nursing home of Jember at varying times. The elderly live in the nursing home of Jember for several reasons, either because they do not have a family or their desire to live in a nursing home. The results of this study are supported by research that has been carried out (Devianto \& Dewi, 2020) based on the length of stay in the institution, most of the elderly have lived in the institution with a range of $1-5$ years, which is $62.7 \%$. Based on gender, it shows that most of the elderly are female (55.4\%). This is because most of the elderly who are willing to become research respondents are female. The results of this study are supported by research that has been carried out (Budiarti et al., 2020) most of the elderly are female (53.2\%). Based on marital status, it shows that most of the elderly are widows/widowers $(73 \%)$. this is because most of the elderly at the nursing home of Jember live alone without a husband/wife or have separated from their partner. The results of this study are supported by research that has been carried out (Umam et al., 2020) that most of the elderly respondents are widows/widowers (89.4\%).

\section{Elderly Social Interaction during COVID-19 Pandemic Independence Indicator}

The results of the study showed that indicators of the independence of the elderly experienced significant changes during the COVID-19 pandemic. This is possible because the question of do you have a regular or routine lifestyle shows meaning. This is in line with research conducted by (Petretto \& Pili, 2020) in Italy which explained that during the COVID-19 pandemic, the elderly carried out their daily activities independently, even in the elderly with one or more chronic diseases. In contrast to research conducted by (Visser et al., 2020) that the COVID-19 pandemic and social distancing are likely to have an impact on the lifestyle behavior of the elderly. Researchers believe that during the COVID-19 pandemic, the elderly at the nursing home of Jember became more independent in meeting their needs and carrying out their daily activities independently, besides that the elderly continued to carry out their routines by participating in activities held by the nursing home to increase the independence of the elderly.

\section{Social Curiosity Indicator}

The results showed that the indicators of social curiosity in the elderly experienced significant changes during the COVID-19 pandemic. This is possible because the question of do you read newspapers regularly shows meaningful. The results of research by (Yuniti et al., 2020) in the province of Bali show that the majority of respondents have high social curiosity, which is $92.56 \%$. The support of science and technology can accelerate the process of disseminating information. In line with research conducted by (Kartikawati et al., 2021) which explains that curiosity about the latest information about COVID-19 is based on information that has been widely circulated in mass media such as television that can provide information about COVID-19. Someone with high social curiosity can lead to starting social interaction with others (Hartung \& Renner, 2011). Researchers argue that social curiosity in the elderly can help the elderly in building good social relationships with each other. Access to information obtained by the elderly at the nursing home of Jember regarding the COVID-19 pandemic as well as matters relating to conditions outside the nursing home is obtained through television, radio, and newspapers.

\section{Interaction Indicator}

The results showed that the elderly interaction indicators experienced significant changes during the COVID-19 pandemic. This is possible because the question of Do you interact with non-family persons regularly shows meaning. In line with research (Loyola et al., 2020) explaining that the application of social distancing practices during the COVID-19 pandemic led to a decrease in elderly interactions because it had limited the social participation of the elderly in their social environment. Supported by research (Dassen et al., 2021) that social distancing prevents the elderly from communicating directly with the surrounding environment so that it has the potential to disrupt the social health of the elderly. Factors that can cause a decrease in elderly interactions are family members and friends of the elderly who often stay away and stop in-person visits to avoid exposure to COVID-19 to the elderly (Macleod et al., 2021). Researchers argue that the existence of social distancing policies during the COVID-19 pandemic causes the elderly to not be able to gather with other elderly people so that the interaction of the elderly in the nursing home is limited.

\section{Participation in the Society Indicator}

The results showed that the indicators of participation in society experienced significant changes during the COVID-19 pandemic. This is possible because the question of do you have a chance to participate in social groups shows meaningful. In line with the research conducted by (Leontjevas et al., 2021) based on the perspective of social health, communication is an important factor to support participation in the social environment. The existence of a travel ban, restrictions on access to and from the nursing home, and participation in various activities during the COVID-19 pandemic can affect social health dimensions such as the ability to participate in social activities. In line with research by 
(Loyola et al., 2020) explaining that the social participation of the elderly during the COVID-19 pandemic has become limited so that the social interaction of the elderly has decreased and has an impact on the mental and physical health of the elderly. Researchers believe that the participation of the elderly in their social environment can affect the physical and mental health of the elderly during the COVID-19 pandemic. The elderly in the nursing home have the opportunity to communicate and participate in activities organized by the nursing home.

\section{Feeling of Safety Indicator}

The results showed that the indicators of feeling safe experienced significant changes during the COVID-19 pandemic. This is possible because the question of do you have someone to support you in an emergency is meaningful. In line with research on the elderly in Switzerland, it shows that a high level of satisfaction with communication can reflect an individual's feeling of comfort in his social circle. This can help the elderly to reduce worries related to stressful events such as the COVID-19 pandemic (Macleod et al., 2021). In contrast to research in Canada by (Herron et al., 2021) that the COVID-19 pandemic and social distancing policies have created more complexity in terms of how the elderly maintain safe social relationships when interacting with others. Researchers argue that the knowledge, attitudes, and behavior of the elderly must be improved in the face of the COVID-19 pandemic to create a feeling of security and peace in the elderly.

\section{Social Interaction}

The results showed that the social interactions of the elderly at the nursing home of Jember experienced significant changes during the COVID-19 pandemic. This was possible because during the COVID-19 pandemic the elderly were unable to gather and interact with other elderly people due to the social distancing policy at the nursing home of Jember. This is in line with research (Emerson, 2020) which explains that the restrictions on social interaction applied in the United States for vulnerable groups have led to the emergence of new problems in the elderly. In line with research (Caoimh et al., 2020) that visits by family and friends are very important for the elderly. The existence of restrictions on visits by family and friends causes the loss of the process of social interaction, thus harming the elderly, family, and friends. Another study by (Bethell et al., 2021) explains that social interaction is an important thing for the mental health of the elderly in nursing homes. Researchers believe that social interaction is important for the elderly because it can help the elderly stay healthy during the current pandemic.

Nurses in providing nursing care to the elderly can use several approaches, namely physical, psychological, social, and spiritual approaches. The social approach that nurses can take is to hold discussions, exchange ideas, and tell stories to create socialization for the elderly (Sunaryo et al., 2015). In a study, it was stated that nursing care that can be given to help improve the social interaction of the elderly is in the form of providing Socialization Group Activity Therapy (TAKS) which is a therapy to facilitate the interaction skills of the elderly and aims to gradually improve social relations in the group. Providing therapy for group socialization activities can train the elderly to improve interpersonal relationships between group members, communicate, pay attention to each other, respond to others, express ideas, and receive external stimuli from the environment (Pambudi et al., 2015). The elderly in the nursing home spend more time with other elderly people telling each other about the problems they are experiencing.

\section{CONCLUSION}

Based on the characteristics of the elderly by age, it is dominated by the elderly aged 69 years. The dominance of the length of stay in the nursing home is 2 years. Gender is mostly female as much as $55.4 \%$. Most of the marital status is widow/widower as much as $73 \%$. Indicators of independence, social curiosity, interaction, participation in the society, and feelings of safety of the elderly experienced significant changes during the COVID-19 pandemic with a $p$-value of 0.000 , and the social interaction of the elderly experienced significant changes during the COVID-19 pandemic with a pvalue 0.045 .

\section{ACKNOWLEDGEMENT}

The preparation of this research can not be separated from the help of various parties. Thank you to all those who have helped in completing this research, one of them is the elderly who live in the nursing home of Jember who have collaborated in assisting researchers in completing the research process properly.

\section{REFERENCES}


Afriansyah, A., \& Santoso, M. B. (2019). Pelayanan Panti Werdha terhadap Adaptasi Lansia. Responsive, 2(4), $190-198$.

Anderson, D. C., Grey, T., Arch, D., Sci, B. A., Kennelly, S., \& Neill, D. O. (2020). Nursing Home Design and COVID-19: Balancing Infection Control, Quality of Life , and Resilience. Journal of the American Medical Directors Association, 21(11), 15191524. https://doi.org/10.1016/j.jamda.2020.09.005

Andesty, D., \& Syahrul, F. (2018). Hubungan Interaksi Sosial dengan Kualitas Hidup Lansia di Unit Pelayanan Terpadu (UPTD) Griya Werdha Kota Surabaya Tahun 2017. The Indonesian Journal, 13(2), 169-180. https://doi.org/10.20473/ijph.vl13il.2018.169-180

Bergman, Y. S., Cohen-fridel, S., Shrira, A., Bodner, E., \& Palgi, Y. (2020). COVID-19 Health Worries and Anxiety Symptoms Among Older Adults: the Moderating Role of Ageism. International Psychogeriatrics, 1-5. https://doi.org/10.1017/S1041610220001258

Bethell, J., Aelick, K., Babineau, J., Ba, M. B., Edwards, C., Ba, J. G., Hewitt, D., Rn, C., laboni, A., Lender, D., Schon, D., \& Rn, K. S. M. (2021). Social Connection in Long-Term Care Homes : A Scoping Review of Published Research on the Mental Health Impacts and Potential Strategies during COVID-19. Journal of the American Medical Directors Association, 22(2), 228-237. https://doi.org/10.1016/j.jamda.2020.11.025

Budiarti, A., Indrawati, P., \& Sabarhun, W. (2020). Hubungan Interaksi Sosial terhadap Tingkat Kesepian dan Kualitas Hidup pada Lansia. Jurnal IImiah Kesehatan, 13(2), 124-133.

Caoimh, R. O., Donovan, M. R. O., Monahan, M. P., Connor, C. D. O., Buckley, C., Kilty, C., Fitzgerald, S., Hartigan, I., \& Cornally, N. (2020). Psychosocial Impact of COVID-19 Nursing Home Restrictions on Visitors of Residents With Cognitive Impairment : A Cross-Sectional Study as Part of the Engaging Remotely in Care ( ERiC ) Project. Original Research, 11, 19. https://doi.org/10.3389/fpsyt.2020.585373

CDC. (2020). Demographic Trends of COVID-19 Cases and Deaths in the US Reported to CDC. https://covid.cdc.gov/covid-datatracker/index.html\#demographics. [Diakses pada 13 Oktober 2020]

Dassen, M. V., Verhey, F., \& Lapid, M. (2021). MThe Risks of Social Distancing for Older Adults : a Call to Balance. International Psychogeriatrics, 32(10), 1235-1237. https://doi.org/10.1017/S1041610220001350

Deputi Bidang Perlindungan Hak Perempuan. (2020). Panduan Perlindungan Lanjut Usia Berperspektif Gender pada Masa Covid19. Deputi Bidang Perlindungan Hak Perempuan Kementerian Pemberdayaan Perempuan dan Perlindungan Anak Republik Indonesia.

Devianto, A., \& Dewi, E. U. (2020). Relationship of Social Interaction with Lonely in Elderly at the Social Service House $X$ Yogyakarta. Journal of Health, 7(2), 37-41.

Emerson, K. G. (2020). Coping with being Cooped up : Social Distancing douring COVID-19 Among 60+ in the United States. Rev Panam Salud Publica, 44, 1-7.

Harahap, S. R. (2020). Proses Interaksi Sosial di Tengah Pandemi Virus Covid 19. Al-Hikmah:Media Dakwah, Komunikasi, Sosial, Dan Budaya, 11(1), 45-53. https://doi.org/10.32505/hikmah.v11i1.1837

Hartung, F. M., \& Renner, B. (2011). Social Curiosity and Interpersonal Perception: A Judge $\times$ Trait Interaction. Personality and Social Psychology Bulletin, 37(6), 796-814. https://doi.org/10.1177/0146167211400618

Herron, R. V., Newall, N. E. G., Lawrence, B. C., Ramsey, D., Waddell, C. M., \& Dauphinais, J. (2021). Conversations in Times of Isolation: Exploring Rural-Dwelling Older Adults' Experiences of Isolation and Loneliness During the COVID-19 Pandemic in Manitoba, Canada. International Journal of Environmental Research and Public Health, 18(3028), 1-15. https://doi.org/10.3390/ijerph18063028

Kartikawati, E., Annisa, R., \& Maesaroh. (2021). Perspektif Sikap IImiah Masyarakat terhadap Pandemi COVID 19. Jurnal Indonesia Sosial Teknologi, 2(1), 49-54.

Kemenkes RI. (2020). Panduan Pelayanan Kesehatan Lanjut Usia pada Era Pandemi Covid-19. Kementerian Kesehatan Republik Indonesia.

Leontjevas, R., Knippenberg, I. A. H., Smalbrugge, M., Plouvier, A. O. A., Teunisse, S., Bakker, C., Koopmans, R. T. C. M., \& Gerritsen, D. L. (2021). Challenging Behavior of Nursing Home Residents dluring COVID-19 Measures in the Netherlands. Aging and Mental Health, 25(7), 1314-1319. https://doi.org/10.1080/13607863.2020.1857695

Li, D., Ko, N., Chen, Y., Wang, P., Chang, Y., Yen, C., \& Lu, W. (2020). COVID-19-Related Factors Associated with Sleep Disturbance and Suicidal Thoughts among the Taiwanese Public. International Journal of Environmental Research and Public Health, 17(4474), 1-12.

Lim, W.-S., Liang, C.-K., Assantachai, P., Auyeung, T. W., Kang, L., Lee, W.-J., Lim, J.-Y., Sugimoto, K., Akishita, M., Chia, S.-L., Chou, M.-Y., Ding, Y.-Y., lijima, K., Jang, H. C., Kawashima, S., Kim, M., Kojima, T., Kuzuya, M., Lee, J., ... Arai, H. (2020). Covid-19 and Older People in Asia. Geriatrics Gerontology International, 1-37. https://doi.org/10.1111/ggi.13939

Loyola, W. S., Rodriguez-Sanchez, I., Rodriguez-Perez, P., Ganz, F., Torralba, R., Oliveira, D. V., \& Rodriguez-Manas, L. (2020). Impact of Social Isolation due to Covid-19 on Health in Older People. J Nutr Health Aging, 1-10.

Macleod, S., Tkatch, R., Kraemer, S., Fellows, A., McGinn, M., Schaeffer, J., \& Yeh, C. S. (2021). Covid-19 Era Social Isolation among Older Adults. Geriatrics, 6(52), 1-15. https://doi.org/10.3390/geriatrics6020052

Pambudi, W. E., Dewi, E. I., \& Sulistyorini, L. (2015). Pengaruh Terapi Aktivitas Kelompok Sosialisasi (TAKS) terhadap Kemampuan Interaksi Sosial pada Lansia dengan Kesepian di Pelayanan Sosial Lanjut Usia (PSLU) Jember. Artikel IImiah Hasil Penelitian Mahasiswa 2015, 5, 1-7.

Petretto, D. R., \& Pili, R. (2020). Ageing and COVID-19: What is the role for elderly people? Geriatrics, 5(25), 1-4. 
https://doi.org/10.3390/GERIATRICS5020025

Quyumi, E., \& Alimansur, M. (2020). Upaya Pencegahan dengan Kepatuhan dalam Pencegahan Penularan Covid-19 pada Relawan Covid. JPH RECODE, 4(1), 81-87.

Sipayung, E. E., Achdiani, Y., \& Jubaedah, Y. (2015). Pelaksanaan Program Pendampingan Lansia di Panti Sosial Tresna Werdha Karitas Cimahi. Jurnal FamilyEdu, 1(1), 50-55.

Sizoo, E. M., Monnier, A. A., Bloemen, M., Hertogh, C. M. P. M., \& Smalbrugge, M. (2020). Dilemmas With Restrictive Visiting Policies in Dutch Nursing Homes during the COVID-19 Pandemic. Journal of the American Medical Directors Association, 21(12), 1774-1781.e2. https://doi.org/10.1016/j.jamda.2020.10.024

Sunaryo, Wijayanti, R., Kuhu, M. M., Sumedi, T., Widayanti, E. D., Sukrillah, U. A., Riyadi, S., \& Kuswati, A. (2015). Asuhan Keperawatan Gerontik. ANDI.

Umam, K., Susanto, J., Dewi, T. T., Wijayanti, E. S., \& Fadliyah, L. (2020). Mental Status with Social Interaction Capacity in the Elderly at Sukodadi Community Health Center, Lamongan Distric. Journal of Vocational Nursing 01, 1(2), 140-145.

Visser, M., Schaap, L. A., \& Wijnhoven, H. A. H. (2020). Self-Reported Impact of the Covid-19 Pandemic on Nutrition and Physical Activity Behaviour in Dutch Older Adults Living Independently. Nutrients, 3708(12), 1-11. https://doi.org/10.3390/nu12123708

Wammes, J. D., Kolk, D., Besselaar, J. H. van den, MacNeil-Vroomen, J. L., Es, B. M. B., \& Rijn, M. van. (2020). Evaluating Perspectives of Relatives of Nursing Home Residents on the Nursing Home Visiting Restrictions during the COVID-19 Crisis. Journal of the American Medical Directors Association, 21(12), 1746-1750.e3. https://doi.org/10.1016/j.jamda.2020.09.031

Wasityastuti, W., Dhamarjati, A., \& Siswanto. (2020). Imunosenesens dan Kerentanan Populasi Lanjut Usia terhadap Coronavirus Disease 2019 (Covid-19). Jurnal Respirologi Indonesia, 40(3), 182-191.

Yuniti, I. G. A. D., Sasmita, N., Komara, L. L., Purba, J. H., \& Pandawani, N. P. (2020). The Impact of Covid-19 on Community Life in the Province of Bali , Indonesia. International Journal of Psychosocial Rehabilitation, 24(10). https://doi.org/10.37200/IJPR/V24I10/PR300214 